\title{
Empowerment and Health Promotion in Hospitals
}

\author{
Sidsel Tveiten
}

\section{Abstract}

Health promotion in hospitals may be an unusual concept to many-experience seems to show that public health and health promotion are considered to be the remit of the local authority. However, hospitals also have responsibility for health promotion. This chapter enlightens empowerment as a concept, a process and an outcome and relates empowerment to health and health promotion in hospitals. Supervision as an empowermentbased intervention is described. The central principles of empowerment can be connected with the central elements of the theory of salutogenesis, recognising patients' selfconsciousness and participation as described at the end of the chapter.

\section{Keywords}

Empowerment · Empowerment interventions · Health promotion $\cdot$ Hospitals $\cdot$ Participation
S. Tveiten $(\bowtie)$

Department of Nursing and Health Promotion, Section of Health Science, Oslo Metropolitan University, Oslo, Norway

e-mail: stveiten@oslomet.no

\subsection{Empowerment as a Concept}

From a scientific perspective, "empowerment" is an immature concept. In other words, it is a broad, vague term that lacks a consensual definition [1]. Consensus means agreement within an academic or professional community around the internal content of a concept. An overview of literature showed that related to health, psychology and pedagogics, there exist 17 definitions of empowerment [2]. In the interest of validity, therefore, it is important to look at some definitions and possible interpretations of empowerment before applying this concept to the hospital context.

The term is a broad one and has connections to many different fields such as occupational psychology, management, health science, pedagogics, social science, politics and democratisation processes. Online searches for the term in scientific databases in 2019 resulted in hundreds of thousands of hits. Both qualitative and quantitative research methods are used in research connected to empowerment.

An immature concept is broadly defined, described and characterised. Immature concepts are easily misused and misunderstood [3-5]. This is confirmed in an academic article that documents and attempts to correct myths and misunderstandings connected to empowerment [6]. Including immature concepts in the production of scientific knowledge implicates the risk of weak- 
ening validity because there is uncertainty as to whether one is actually studying what one thinks one is studying. The concept appears in administrative letters from the 1700s [7]. From around 1970 , the concept is found in scientific literature connected to the civil rights movement in the USA and other democratisation processes [8, 9].

The New International Webster's Comprehensive Dictionary of the English Language [10] defines "empower" as (to) "give authority to", "delegate authority to", "commission" or "permit". Illustrated Oxford Dictionary [11] defines empowerment as "to authorise", "give permission to", "give power to" or "put in working order". These definitions may seem paternalistic, which in itself is incompatible with what is implied by the term, namely democratisation. To give someone authority or to delegate authority implies that someone is in possession of that authority and consequently passes it on or delegates it further. One may wonder whether there are conditions attached to this delegation.

\subsection{Empowerment and Health}

The Ottawa Conference in 1986 represents kind of a shift in paradigm regarding health, from paternalistic to democratic [12]. The World Health Organization (WHO) declared that it was necessary to pay more attention to health promotion within the health care services, arguing that people had to take more responsibility for their own health [12]. The main idea was to redistribute power, from the health professionals to the patients, and the term "The new public health" was introduced by the WHO, underlining this increased attention.

Within the health (and social) care fields, the concept of empowerment is linked to individuals and groups who are/have been in a situation of powerlessness and how they can emerge from that powerlessness [9]. Illness and symptoms such as severe pain, nausea and discomfort, or fear and exhaustion can easily contribute to feelings of powerlessness.

A frequently used definition in health contexts describes empowerment as giving someone the authority or power to do something, “...to make someone stronger and more confident, especially in controlling their life and claiming their rights" [13]. However, this definition too, may be perceived as paternalistic.

A concept analysis of empowerment within an health care context published in 2014 showed that empowerment is characterised by active participation, informed change (change that one undertakes after attaining relevant knowledge, e.g. about the significance of a better diet and physical activity), knowledge to problem solve, self-care responsibility, sense of control, awareness, development of personal abilities, autonomy and coping [14].

Another concept analysis concludes that individual patient empowerment is a process that enables patients to exert more influence over their individual health by increasing their capacities to gain more control over issues they themselves define as important. The authors combine patient empowerment with patient participation and patient centredness and state that patient participation might lead to patient centredness that at last can lead to patient empowerment [15].

A study of the principles of empowerment in a psychiatric context showed that the patients found it difficult to understand every decision in relation to what was "allowed and not allowed" and to understand the reasons given by the staff for implementing measures within the department. Similarly, they found it difficult to be perceived as experts on themselves [16]. Another study on the perception of empowerment among elderly people with diabetes indicated the same challenges [14]. A literature review and a concept analysis of empowerment in critical care showed that the common attributes of empowerment were a mutual and supportive relationship, skills, power within oneself and self-determination. The author concludes that even if empowerment is sparsely used in relation to critical care, it appears to be a very useful concept in this context [17].

Rapaport [18] once claimed that it is easier to define the opposite of empowerment: powerlessness or learned helplessness, alienation and the perception of not having control over one's own life. This is a particularly interesting observation for our context. The health service and hospitals in particular can easily be perceived as paternal- 
istic, and it can be difficult to participate and be acknowledged as an expert on oneself as a patient. It is easy to fall into the traditional role of patient and leave decisions to the professionals, to be taught helplessness and feel powerless.

The concept of empowerment is of particular interest to the health professions [8]. This is because the concept underscores the importance of supporting people who find themselves in a vulnerable situation and because the concept per se emphasises the importance of seeing people as actors in their own lives who "know best where the shoe pinches" $[19,20]$. It is precisely this, supporting someone in a vulnerable position, while not taking over but helping the person to take as much control as possible that is challenging in relation to empowerment in hospitals. Most patients may be able to participate a little in some areas.

\subsubsection{Empowerment as a Process}

The empowerment process can be described as a social and a helping process, as well as a dynamic and interactive process $[14,17,21,22]$. Describe how the empowerment process in elderly care claims that the health professionals surrender control. To surrender control might be easier said than done to the health professionals [23, 24]. The health professionals themselves often define the needs of the patients and even how to meet those needs.

Askheim [9] claims that empowerment is characterised by a positive view of the individual and by the individual as active and acting in their best interests where the right conditions are in place. Empowerment is further characterised as a concept that has an emotional dimension [9]. The individual is not always rational, and situations that may involve, e.g. shame and dejectedness or enthusiasm, and the joy of mastery may influence the empowerment process.

When studied from the perspective of the individual, empowerment is called "psychological empowerment". Empowerment may also be studied from a group, organisation or societal perspective. Further, empowerment can be studied from a systemic perspective, e.g. structural empowerment. All levels of empowerment are connected. The system holds major significance for psychological or individual empowerment [25].

Psychological empowerment is based on social psychology theory and developmental psychology and builds on the assumption that empowerment centres around internal, psychological processes such as perceptions of selfdetermination, impact, competence and meaning [7, 26, 27]. Individual or psychological empowerment is about the individual's ability to make decisions and have control over his/her own life [28] and about self-control, belief in and opportunities for one's own efficacy (efficacy expectation or self-efficacy) [29].

Structural empowerment deals with a person's power with regard to his/her position within the organisation. Kanter [30] describes four empowerment structures: opportunity, information, support and resources. Structural empowerment may be understood as the structures in which the patient is a part representing opportunities for or obstacles to empowerment. Specifically, systems that provide opportunities for participation, such as joint meetings in mental health care settings where the patient is able to influence conditions within the department, represent an example of structural empowerment, along with procedures or systems gathering information about patients' experiences, views and needs during conversations. A study of patients' perceived opportunities for participation at an outpatient pain clinic showed that the patients perceived that their participation was obstructed by an inability to understand their treatment plan. The patients also had very limited knowledge about their rights in relation to participation [25].

Gibson [31] defines empowerment as a social process that contributes to recognising, promoting and enhancing people's abilities to meet their own needs, solve their own problems and mobilise the necessary resources in order to feel in control of their own lives or the factors which affect their health. The definition is still used in scientific articles despite the year of publication, so long ago. This definition emphasises the social 
process between health professional and patient. Being a partner in an empowerment process requires the health professional to adopt a different role than that of traditional assistant who solves problems for the patient: the health professional takes on a supervisory role [32]. In this context, the affective dimension is significant. The affective dimension deals with the way the health professional relates to the patient, whether she communicates respect, empathy or understanding, for example, or conveys that she is short on time, appears impatient or is inattentive to the patient. According to Askheim and Starrin [8], it is precisely this emotional dimension between helper and helpee (here: patient) that is important in empowerment.

\subsubsection{Public Health and Health Promotion}

What is public health and what does it have to do with hospitals? In 1920, public health was defined as: "The science and art of preventing disease, prolonging life and promoting health through the organized efforts and informed choices of society, organizations, public and private, communities and individuals". This definition is still used ([33], pp. 17-18). Public health can be understood as society's responsibility for the health of the people, or society's duty to protect, promote and strengthen people's health. Public health can also be understood as the duty of medicine to protect and improve the health of the nation [34].

Public health work may further be understood as the collective effort of society to strengthen factors promoting health, to reduce factors that result in increased health risks and to protect against external threats to health and as the practical means by which information about the science of public health is applied for the purpose of promoting health [35]. Health promotion and disease prevention are forms of intervention in public health work. The Ottawa Charter provides guidelines for substantially strengthening health promotion work [12]. Health promotion and preventing disease are strategies that overlap to a certain degree.

\subsubsection{Health}

Views on health hold significance for health promotion work. WHO's definition of health from 1948 [36] was somewhat expanded in 1986 [12], and emphasis was placed on the significance of well-being and quality of life [37]. In the 1946 definition [38], health was understood as more than just absence of disease and as complete physical, mental and social well-being. WHO later modified the definition and describes health as the ability to live an economically and socially productive life [39]. Hjorth [40] describes health as the ability to cope and function in one's current context and with the challenges one may face at any time. Health is understood as a resource that gives people the strength and resilience to endure stresses and strains [39].

Views of health reflect ideology, value-based priorities and cultural and social relations. In recent times, the term "health" has to some extent been replaced by "quality of life" [39]. Fugelli and Ingstad [41] describe health as an ephemeral phenomenon that shifts between time and space and is both individual and general. Health professionals are supposed to contribute to health promotion, prevent disease, alleviate suffering and restore health. Health promotion work centres around how one lays the groundwork for the individual to feel more in control over his/her life and health. Health promotion work focuses on empowerment principles (redistribution of power, participation and acknowledging) and building capacity within the individual and the local community. Participation through involving people in decisions about their lives and health is one part of this work [42].

\subsubsection{Empowerment and Health Promotion}

Since the 1970s, empowerment has been defined as a central concept in health promotion work, and Andrews and Rootman et al. [43, 44] state that empowerment represents a framework for health promotion. The Brazilian educator Paulo Freire [45] focused his pedagogical efforts on the 
poor of Brazil in the 1960s and was particularly interested in how the situation these people found themselves contributes to oppression. Freire believed that what was most important for the poor and oppressed was to become conscious of why they were oppressed, because this awareness could help them change their behaviour and thereby create a new situation for themselves. Consciousness raising is therefore important to be able to take control of one's own life. According to Freire, the central method of this liberation was dialogue [45]. Dialogue as a method of health promotion will be discussed later in this chapter.

Empowerment may be a social, cultural, psychological or political process through which individuals and social groups are able to express their needs, present their concerns, devise strategies for involvement in decision-making and achieve political, social and cultural action to meet those needs. Through such a process, people see a closer correspondence between their goals in life and a sense of how to achieve them and a relationship between their efforts and life outcomes. Health promotion not only encompasses actions directed at strengthening the basic life skills and capacities of individuals, but also at influencing underlying social and economic conditions and physical environments which impact upon health. In this sense health promotion directs creating conditions facilitating a relationship between the efforts of individuals and groups, and subsequent health outcomes in the way described above.

A distinction is made between individual and community empowerment. Individual empowerment refers primarily to the individuals' ability to make decisions and have control over their personal life. Community empowerment involves individuals acting collectively to gain greater influence and control over the determinants of health and the quality of life in their community and is an important goal in community action for health. In health promotion, enabling involves taking action in partnership with individuals or groups to empower them, through the mobilisation of human and material resources, which are important to promote and protect their health.
The World Health Organisation ([46], p. 11) provides the following description of empowerment: "Patient and consumer empowerment has emerged in the last decades as a proactive partnership and patient self-care strategy to improve health outcomes and quality of life". In this description, empowerment is thus linked to health and quality of life.

One may wonder whether the philosophy of empowerment is universally appropriate. What about the seriously ill and children? What about people who are unconscious? It is the most seriously ill who are admitted to hospital. This issue touches on the central principles of empowerment. What does participation entail? Participation can be ranked and seen in the context of the patient's capacity level at any time. One can participate a little; for example, one can participate in relation to what one would like to drink, whether one wants to sit up or lie down in bed. It is easy to make such choices on behalf of the patient. To find anything out about the patient's capacity, the health professional must be attentive, aware of his/her interactions and acknowledge the patient's competence at all times. In this context, affective competence is of particular importance. In encounters with unconscious patients, who has not whispered into the patient's ear that he/she must squeeze your hand if they can hear what you are saying? This is an example of acknowledging the patient's personal competence and inviting him/her to participate. This involves a kind of redistribution of power. In this context, it is also appropriate to see the patient and his/her next of kin as one unit.

\subsection{Empowerment and Health Promotion in Hospitals}

Our context is empowerment in connection with health promotion in hospitals. The guidelines in the Ottawa Charter place greater emphasis than before on health promotion and described health promoting strategies as "the new public health". The guidelines centre around giving special priority in health promotion work to the redistribution of power from professional to patient or user, 
participation and acknowledgement of the patient's [12]. WHO further states that empowerment means:

\footnotetext{
“...the process of increasing capacity of individuals or groups to make choices and to transform those choices into desired actions and outcomes" to "build individual and collective assets, and to improve the efficiency and fairness of the organizational and institutional context which govern the use of these assets" and the "expansion of assets and capabilities of poor people to participate in, negotiate in, negotiate with, influence, control, and hold accountable institutions that affect their lives “ ([12], p. 17).
}

Health promotion in hospitals has to do with the interaction between patients and health professionals and the hospital as the system within which this interaction takes place. Health promotion is about helping the patient to participate in his/her own treatment and care, acknowledging the patient's self-competence and redistributing power. Health promotion is about everything we do to enable the patient to develop or improve competence in relation to sustaining health and quality of life. You may be forgiven for thinking that such interactions take too much time in hospitals and that seriously and/or acutely ill people do not need or have the energy to participate. Of course, this may be the case, but health professionals cannot take it for granted. In interactions with the patient, health professionals can identify the patient's needs in relation to participation. Expressing that one does not wish to participate is in itself a form of participation. Again, it is important to be aware that one can participate a little and in certain areas. Acknowledgement may also be expressed in many ways. A seriously ill patient may for example feel acknowledged by the health professional communicating empathy and respect. WHO has provided guidelines for the recognition of Health Promoting Hospitals and has set up a network for these hospitals [47]. All health trusts and organisations interested in public health and willing to follow the WHO concept of Health Promoting Hospitals can become members. Membership in the network can be seen as an aspect of empowerment at the system level.
There are several examples of health promotion in hospitals. For example, some hospitals have "patient schools" for patients with heart disease, diabetes, stomas or breast cancer. These patient schools offer for example teaching and supervision that is intended to help patients cope with their symptoms and treatment. However, studies emphasise that competence in health education is crucial for ensuring that patients and service users derive benefit from the patients' schools or programs [48].

\subsection{Empowerment-Based Interventions}

As we have seen, the central principles of empowerment are power redistribution, participation and being acknowledged as an expert on oneself. These principles are connected; one is virtually a natural consequence of the other. The principles will be preserved through the interaction between health care professionals and patients [12]. The strategies for this interaction can be described as empowerment "interventions". These are interventions that aim to develop competence and coping skills or that help patients cope as well as possible with health challenges and their attendant consequences [49-51]. The empowerment interventions must be commensurate with the patient's competence, for example, the patient's resources, needs and opportunities to participate.

\begin{abstract}
Empowerment-based interventions include both a process and an outcome component. The process component occurs when the true purpose of the intervention is to increase the patient's capacity to think critically and make autonomous, informed decisions. The outcome component occurs when there is a measurable increase in the patient's ability to make autonomous, informed decisions ([6], p. 278)
\end{abstract}

The result of empowerment may be described as coping [49]. Coping may be understood as ever-changing cognitive and behavioural efforts to manage specific external and/or internal challenges that are perceived as burdensome or that adversely affect the resources one has at one's disposal $[52,53]$. Coping can also be understood 
as attempts by the individual to manage challenge or stressful situations. Vifladt and Hopen [54] define coping as "the perception of having the resources to face challenges and a sense of having control over one's own life. Active and effective coping helps you to adapt to new realities and enables you to see the difference between the things you have to live with and the things you can play a part in changing" ([54], p. 61, translated by the author).

The concept of compliance is interesting in this context. Traditionally, the term denotes manageability or assent, or the patient's ability to follow the doctor's advice. According to Fielding and Duff [55], "compliance" can have a deeper meaning; the ability to take control of the factors that affect your health. In other words, not just following advice, but playing an active role, responding actively to advice, speaking up when advice is not perceived as beneficial, for example. "Compliance" can also be understood as an active, intentional and responsible process [56]. In concrete terms, this means the ability to understand and act in relation to changing symptoms and to understand and act when treatment perhaps does not work the way it was supposed to. Another interpretation of "compliance" leads to empowerment. "Compliance" is influenced by age, socio-economic circumstances, how one copes with having an illness and by psychological stress. "Compliance" may be strengthened by education, reflection, emotional processing and skills training [55].

Patient education is recognised as an important part of the nurse's role and includes patient teaching, advice and information-giving as well as supervision. The purpose of patient and eventually next of kin education is to contribute to improving health and quality of life and help patients and next of kin cope with illness and/or functional impairment. Further, education can lead to patients being able to make informed choices together with their health care providers. The hospitals must also contribute to healthpromoting processes through interaction with the individual patient and his/her next of kin and groups of patients and next of kin. Patient and next of kin education can therefore be seen as health-promoting work at the hospital [20, 51].

Supervision is an empowerment-based intervention. The concept of supervision might seem unusual regarding patients and next of kin, since the concept usually is related to health professionals or students [57]. Supervision may be defined as: A formal, relational and pedagogical process that enables, and that aims to strengthen personal mastery competence through a dialogue based on knowledge and humanistic values [32, 58]. This definition emphasises the relationship between health professional and patient. It is through this relationship that the health professional gains insight into the patient's thoughts, perceptions and needs. The affective aspect of the interaction centres around laying the foundations for trust and meeting the patient where he/she is. Health-promoting measures can thus be customised.

Dialogue requires the health professional to be a skilled listener. The dialogue entails reflection, in the sense of exchange. The health professional must listen to the patient and tell the patient his/her perception of what the patient is saying and of the situation the patient is in. Thus, exchange and reflection take place. This creates an enhanced mutual understanding of the patient's situation, and further health-promoting measures are implemented in line with the patient's needs.

The purpose of supervision is to strengthen coping competence. What to be overcome is individual, situational and contextual. Coping competence includes knowledge, abilities and attitudes. All these aspects are important in the supervision dialogue. A patient in hospital may be in an acute state of illness or injury and may be dealing with pain, fear or reduced consciousness. The dialogue with the patient must be informed by the patient's condition. It would be easy to think that the most seriously ill patients have no need for dialogue. However, assessment of the patient's competence must be ongoing. A dialogue with a patient may, for example, involve investigating what the patient knows about the illness and treatment options, and conveying to 
the patient the information that he/she needs in order to understand, actively participate and make choices. Dialogue entails helping the patient to gain a deeper understanding.

An example from a hospital, as told by the patient's next of kin:

An 80-year-old man with stomach pains was an
emergency admission to the hospital. He was lucid
and oriented and was lying in bed when his next of
kin arrived. A nurse arrived at the same time and
asked if the man would like something to drink. The
man answered "Yes please..." and a glass of fruit
cordial was placed on the bedside table. The next
of kin asked if the man would like to sit up to make
it easier for him to drink the cordial. The man
answered that he was unsure whether he was
allowed to sit up. The next of kin left the room,
located the nurse and asked if it was OK for the
man to sit up in bed. The nurse replied that of
course it was OK, he could even get out of bed if he
wanted to. The patient later said that he had been
lying on his back in bed since he was admitted two
days ago, no-one had informed him that he was
free to move around, and he had not asked any
questions.

This is an example of a patient feeling powerless and presenting learned helplessness, but it is also an example of the importance of providing supervision to patients to enable them to start using their own resources. Knowing that one can safely get out of bed and move around is of major significance in terms of health. Being bed-bound may in itself cause complications due to inactivity. This is also an example of when a dialogue with the patient may have had a health-promoting effect. The purpose of the dialogue is to produce an enhanced understanding of what the dialogue is about. It is of major importance in terms of coping that patients understand and can appropriately relate to the information they are given, e.g. about medicines and treatment. This is known as "health literacy" [59].

Health literacy concerns the knowledge and competences of persons to meet the complex demands of health in modern society and can be defined as "people's knowledge, motivation and competence to access, understand, appraise, and apply health information in order to make judgements and take decisions in everyday life con- cerning health care, disease prevention and health promotion to maintain or improve quality of life during the life course" ([60], p. 3). Health literacy may also be defined as the use of medical terminology that may for example prevent a patient from understanding. The patient's health literacy is an important factor in empowerment and health promotion work [61].

There are many ways to provide supervision and dialogue: solution-focused guidance, changefocused guidance or counselling, empathic communication, health coaching, shared decision-making, or motivational interview, to name just a few [20]. Patients in hospital may be facing multiple choices in relation to treatment, lifestyle and follow-up. Actively participating in choices requires, among other things, awareness, understanding, knowledge and skills. In this context, supervision is a relevant method.

To fulfil their health-promoting duty, health professionals need pedagogical competence or competence related to health pedagogics. Health pedagogics may be understood as everything that is connected to development, learning, teaching and supervision in a health-related setting [20, 62]. The purpose of health pedagogics is to encourage the patient to change his/her relationship to his/her own health and lifestyle [63]. The concept of health competence is recently used to describe the result of health education and is in Norway defined as a consensus concept connected to health literacy [64]. Health pedagogics is the general term we use to denote everything we do as health professionals (e.g. empowerment interventions, training and supervision) to strengthen the patient's and next of kin's ability to cope with health-related challenges and to achieve health competence.

\subsection{Some Empirical Studies}

In an intervention study, the purpose of which was to look at the empowerment process in the rehabilitation of women with breast cancer, Stang and Mittelmark [65] found that self-help groups as intervention resulted in consciousness raising. 
Knowledge building, community learning and discovering new perspectives contributed to the consciousness raising. Consciousness raising, as we saw earlier, is a prerequisite for empowerment [45].

Anderson and Funnell's [6] study shows that implementing empowerment interventions entails a type of paradigm shift that can be complex because the education received by health professionals taught more traditional types of intervention. Empowerment interventions may involve new and different ways of relating to patients and require the ability of self-reflection. Ruud Knutsen and Foss [66] studied understandings of and strategies for empowerment in lifestyle change courses at one hospital's Learning and Mastery Centre. The analysis showed that when health professionals develop empowerment interventions, it is essential to be aware of the power dynamic that will always be present in relation to patients in this context. Power can lie within systems.

Communication between health professionals and patients is an important factor in interactions. Cegala et al. [67] concluded in their study that when the parents of sick children are active communicators, the surgeon will provide more information. When parents are more active, this may lead to them receiving clarification on what they were unsure about. This promotes empowerment. In a systematic literature review, Pearson [68] showed that involving patients in goal-setting processes for lifestyle change may be useful. In addition, a questionnaire conducted by Rosenlund et al. [69] shows that patients value communication when they themselves are active. When the patient is active, empowerment is promoted. A quantitative study of patients' experiences with the empowerment process concludes that it is of importance regarding quality of life and health outcomes that health professionals actively ask for the patients' experiences of the process or how it felt to participate and being acknowledged [70]. Stiffler et al. [71] conclude in a qualitative study that the interaction between the patient and the health professionals was more important to the patient than medical control regarding the disease.
Studies of health education interventions are often related to specific diagnoses. For example, one study of patient experiences connected to diagnosis-specific health education interventions showed limited effects [72]. Perhaps it would be more useful to carry out training irrespective of diagnosis and based on the needs of the individual. The need for a scientific basis for the development of strategies for health education is confirmed by Smith et al. [73], who concluded that much of the material being used in this context is outdated. However, one may argue that the patient's perspective and participation challenge equality in the relationship between the patient and the health professionals due to the fact that the health professionals themselves often define the patient's needs and goals [24]. The health professionals need health education competence or health pedagogy competence in order to practice in line with the empowerment principles. Research regarding this area sparsely exists. Therefore, qualitative as well as quantitative studies are of high importance in the future, and there is a need of further developing healthpromoting strategies and education of health professionals within health pedagogy [48].

\subsubsection{Empowerment and Salutogenesis}

As we have seen in this chapter, central principles of empowerment are distribution of power from the health professionals to the patients, patient participation and acknowledging the patient as an expert regarding herself/himself. Antonovsky's theory of salutogenesis [74] emphasises positive aspects of health and well-being. A key component in the theory is "sense of coherence" (SOC). This component has a particular relevance to health promotion, since it represents characteristics that contribute to help individuals gain control:

The sense of coherence is... a global orientation that expresses the extent to which one has a pervasive, enduring though dynamic feeling of confidence that one's internal and external environments are predictable and that there is a high probability 
that things will work out as well as can reasonably be expected. ([74], p. 122)

The elements of coherence are comprehensibility, which means that the world is ordered consistent, structured and clear and that the future is predictable rather than noisy, chaotic, disordered, random, accidental and unpredictable. Further, manageability, which means that individuals believe that they have the resources at their disposal which can help them to manage their lives. Meaningfulness means that life make sense emotionally, that people are committed and that they invest energy in worthwhile goals $[74,75]$. The elements of SOC can be viewed as interrelated with the principles of empowerment, to take control in one's life and to obtain power within oneself claims self-consciousness and participation. SOC claims self-consciousness and participation as well.

\section{Take Home Messages}

- Empowerment can be understood as a concept, a process and an outcome.

- Empowerment can be a health promotion strategy (empowerment-based interventions) in hospitals.

- Acting or interacting in line with the principles of empowerment philosophy, power redistribution, participation and acknowledgement of the patient's competence is complex.

- Health promotion and empowerment-based interventions (e.g. supervision) require health education skills.

- Knowledge-based practice is a goal for the health service. There is a great need for scientific knowledge related to empowermentbased interventions in hospitals.

- The principles of empowerment connect with the central elements of the salutogenic theory.

\section{References}

1. Istomina N, Suominen T, Razbadauskas A, Martikenas A, Kuokkanen L. Lithuanian nurses' assessment of their empowerment. Scand J Caring Sci. 2011;26:3. https://doi.org/10.1111/j.1471-6712.2011.00894.x.

2. Cerezo PG, Juvè-Udina ME, Delgado-Hito P. Concepts and measures of patient empowerment: a comprehensive review. Rev Esc Enferm USP. 2016;50(4):664-71.

3. Morse JM. Exploring the theoretical basis of nursing using advanced techniques of concept analysis. Adv Nurs Sci. 1995;17(3):31-46.

4. Morse JM, Mitcham C, Hupcey JE, Cerdas Tason M. Criteria for concept evaluation. J Adv Nurs. 1996a;24:385-90.

5. Morse JM, Hupcey C, Lenz ER. Concept analysis in nursing research: a critical appraisal. Sch Inq Nurs Pract. 1996b;10(3):253-77.

6. Anderson RM, Funnell M. Patient empowerment: myths and misconceptions. Patient Educ Couns. 2010;79:277-82.

7. Kuokkanen L, Leino-Kilpi H. Power and empowerment in nursing: three theoretical approaches. J Adv Nurs. 2000;31:235-41.

8. Askheim OP, Starrin B. Empowerment i teori og praksis [empowerment in theory and practice]. Oslo: Gyldendal Academic; 2007.

9. Askheim OP. Empowerment i helse- og sosialfaglig arbeid: floskel, styringsverktøy eller frigjøringsstrategi? [Empowerment in health and social work: meaningless jargon, management tool or strategy for liberation?]. Oslo: Gyldendal Academic; 2012.

10. Wbster's Comprehensive Dictionary of the English language. 1996.

11. Illustrated Oxford Dictionary. Oslo: Teknologisk forlag; 1998.

12. World Health Organization. The Ottawa charter for health promotion. Geneva: WHO; 1986.

13. Pearsall J, editor. The new Oxford dictionary of English. Oxford: Clarendon Press; 1998.

14. Fotoukian Z, Shahboulaghi FM, Khoshknab MF, Mohammadi E. Concept analysis of empowerment in old people with chronic diseases using a hybrid model. Asian Nurs Res. 2014;8:118-27.

15. Castro EM, Van Regenmortel T, Vanhaecht K, Sermeus W, Van Hecke A. Patient empowerment, participation and patient-centeredness in hospital care: a concept analysis based on literature review. Patient Educ Couns. 2016;99:1923-39.

16. Tveiten S, Haukland M, Onstad RF. The patient's voice-empowerment in a psychiatric context. Nord J Nurs Res. 2011;101(31):20-4.

17. Wählin I. Empowerment in critical care-a concept analysis. Scand J Caring Sci. 2016;31:164-76. https:// doi.org/10.1111/scs.12331.

18. Rapaport J. Studies in empowerment: introduction to the issue. Prev Hum Serv. 1984;3:1-7.

19. Tveiten S. Den vet best hvor skoen trykker...om veiledning I empowermentprosessen. [the wearer knows best where the shoe pinches... On supervision in the empowerment process]. Bergen: Fagbokforlaget; 2007.

20. Tveiten S. Helsepedagogikk (Health Pedagogics). Bergen: Fagbokforlaget; 2016.

21. McCarthy V, Holbrook Freeman L. A multidisciplinary concept analysis of empowerment: 
implications for nursing. $\mathrm{J}$ Theor Construct Test. 2008;12(2):68-74.

22. Bennett L, Bergin M, Wells SG. The social space of empowerment within epilepsy services: the map is not the terrain. Epilepsy Behav. 2016;56:139-48.

23. Tveiten S, Meyer IS. «Easier said than done»empowering dialogues with patients at the pain clinic. J Nurs Manag. 2009;17:804-12.

24. Tveiten S, Onstad RF, Haukland M. Refleksjon over praksis i lys av empowerment-en fokusgruppeundersøkelse (Reflections on practice in the light of empowerment-a focus group study). Nord J Nurs Res. 2015;35:136-43.

25. Tveiten S, Ruud Knutsen I. Empowering dialoguesthe patients' perspective. Nord Coll Caring Sci. 2010. https://doi.org/10.1111/j.1471-6712.2010.00831.x.

26. Spreitzer GM. Psychological empowerment in the workplace: dimensions, measurement, and validation. Acad Manage J. 1995;38(5):1442-65. https://doi. org/10.2307/256865.

27. Knol J, van Linge R. Innovative behaviour: the effect of structural and psychological empowerment in nurses. J Adv Nurs. 2009;65(2):359-70.

28. Israel BA, Checkoway B, Schulz A, Zimmerman M. Health education and community empowerment: conceptualization and measuring perceptions of individual, organizational and community control. Health Educ Q. 1994;21(2):149-70.

29. Wallerstein N. Power between evaluator and community relationships with New Mexico's healthier communities. Soc Sci Med. 1999;49(1):39-53.

30. Kanter RM. Men and women of the corporation. New York: Basic Books; 1993.

31. Gibson CH. A concept analysis of empowerment. J Adv Nurs. 1991;16:354-61.

32. Tveiten S. The public health nurses' client supervision. Doctoral thesis. University of Oslo; 2006.

33. Småland Goth U, editor. Folkehelse i et norsk perspektiv [public health from a Norwegian perspective]. Oslo: Gyldendal Academic; 2014.

34. Last JM. A dictionary of epidemiology. New York: Oxford University Press; 1995.

35. Dreyer Fredriksen ST. The enigmatic knowledge of intensive care patients - experience and interpretation based knowledge in intensive care tutoring. Doctoral thesis. Nordic College for Public Health and Harstad University College; 2011.

36. United Nations Department of Public Information. The universal declaration of human rights. 1948. https:// www.un.org/en/universal-declaration-human-rights/.

37. Sletteland N, Donovan RM. Helsefremmende lokalsamfunn. [the health-promoting community]. Oslo: Gyldendal Academic; 2012.

38. World Health Organisation. Constitution. 1946. www. who.int/about/who-we-are/constitution.

39. Mæland JG. Forebyggende helsearbeid i teori og praksis [Preventive health work in theory and practice]. Oslo: Universitetsforlaget; 2016.

40. Hjorth PF. "Om samsykdommene" [On psycho-social disease]. I: Hjorth, P. F. Helse for alle! [Health for
Everyone!] Foredrag og artikler [Essays and articles] 1974-1993. Investigation report no. U1-1994. Oslo: The Norwegian Institute of Public Health, Section for Health Services Research; 1994.

41. Fugelli P, Ingstad B. Helse på norsk [Norwegian perspectives on health]. Oslo: Ad Notam Gyldendal; 2009.

42. Mittelmark M, Kickbusch I, Rootman I, Scriven A, Tones K. Helsefremmende arbeid - ideologier og begreper [Health promotion work-ideologies and concepts]. In: Gammersvik $\AA$, Larsen $\mathrm{T}$, editors. Helsefremmende sykepleie [Health promotion in nursing]. Bergen: Fagbokforlaget; 2012.

43. Andrews T. "New" ideological basis for preventive health work. A discussion on views of power and change. Norwegian J Welfare Res. 2003;6(1):30-42.

44. Rootman I, Goodstadt M, Potvin L, Springett J. A framework for health promotion. WHO Regional Publication European Series, vol. 92; 2001. p. 7-38.

45. Freire P. Pedagogy of the oppressed. Oslo: Ad Notam Gyldendal; 1999.

46. World Health Organization. What is the evidence of effectiveness of empowerment to improve health? Geneva: WHO; 2006.

47. Johnson A, Baum F. Health promoting hospitals: a typology of different organizational approaches to health promotion. Health Promot Int. 2001;16(3):281-7.

48. Vågan A, Eika K, Skirbekk H. Helsepedagogisk kompetanse, læring og mestring (Health pedagogic competence, learning and coping). Sykepleien.no/ Forskning; 2018. https://doi.org/10.4220/sykepeleien f.2006.59702s.

49. Espnes GA, Smedslund G. Helsepsykologi [Health Psychology]. Oslo: Gyldendal Academic; 2009.

50. Lerdal A, Fagermoen MS. Learning and mastery-a health promotion perspective in practice and research. Oslo: Gyldendal Academic; 2011.

51. Crawford T, Roger P, Candlin S. The interactional consequences of "empowering discourse" in intercultural patient education. Patient Educ Couns. 2017;100:495-500.

52. Lazarus RS, Folkman S. Stress, appraisal and coping. New York: Springer; 1984.

53. Folkman S, Lazarus BS. The relationship between coping and emotion: implications for theory and research. Soc Sci Med. 1988;26:309-17.

54. Vifladt E, Hopen L. Helsepedagogikk-Samhandling om læring og mestring [health education-interaction in learning and mastery]. Oslo: Norwegian National Advisory Unit on Learning and Mastery in Health; 2004.

55. Fielding D, Duff A. Compliance with treatment protocols: intervention for children with chronic illness. Arch Dis Child. 1999;80:196-200.

56. Kyngäs H. A theoretical model of compliance in young diabetics. J Clin Nurs. 1999;8(1):73-80.

57. Tveiten S. Evaluation of the concept of supervision related to public health nurses I Norway. J Nurs Manag. 2005;13:13-21. 
58. Tveiten S. Veiledning, mer enn ord...(Supervision, more than words...). Bergen: Fagbokforlaget; 2019.

59. Carolan M. Health literacy and the information needs and dilemmas of first-time mothers over 35 years. J Clin Nurs. 2007;16:1162-72.

60. Sørensen K, Van den Broucke S, Fullam J, et al. Health literacy and public health: a systematic review and integration of definitions and models. BMC Public Health. 2012;12:80. http://www.biomedcentral.com/1471-2458/12/80.

61. Sand-Jecklin K, Coyle S. Efficiently assessing patient health care literacy: the BHLS instrument. Clin Nurs Res. 2014;23:581. https://doi. org/10.1177/1054773813488417.

62. Tveiten S. Empowerment og veiledning-sykepleierens pedagogiske funksjon $\mathrm{i}$ helsefremmende arbeid [Empowerment and supervision-the pedagogical role of the nurse in health promotion work]. In: Gammersvik ^̊, Larsen T, editors. Helsefremmende sykepleie [Health promotion in nursing]. Bergen: Fagbokforlaget; 2012.

63. Holman HR, Lorig KR. Patient education: essentials in good health care for patients with chronic arthritis. Rheumatology. 1997;40(8):1371-3.

64. The Health and Caring Department, Norway. Strategy to develop the health of the population. 2019.

65. Stang I, Mittelmark M. Learning as an empowerment process in breast cancer self-help groups. J Clin Nurs. 2008;18:2049-57.

66. Ruud Knutsen I, Foss C. Caught between conduct and free choice-a field study of an empowering programme in lifestyle change for obese patients. Scand J Caring Sci. 2010. https://doi. org/10.1111/j.1471-6712.2010.00801.x.

67. Cegala DJ, Chisolm DJ, Nwomeh BC. Further examination of the impact of patient participation on physicians' communication style. Patient Educ Couns. 2012;89:25-30.
68. Pearson ES. Goal setting as a health behavior change strategy in overweight and obese adults: a systematic literature review examining intervention components. Patient Educ Couns. 2011;87:32-42.

69. Rosenlund Lau S, Christensen ST, Andersen JT. Patients' preferences for patient-centered communication: a survey from an outpatient department in rural Sierra Leone. Patient Educ Couns. 2014;93:312-8.

70. Chen M-F, Tsai CT, Hsu S-M, Tu S-Y, Kao P-L, Chen S-L. Patient perceptions of empowerment processes, health outcomes and related factors in living with diabetes in Taiwan: a cross-sectional survey. J Community Health Nurs. 2013;30:201-15.

71. Stiffler D, Cullen D, Luna G. Diabetes barriers and self-care management: the patient perspective. Clin Nurs Res. 2013;23(6):601-26.

72. Hamilton Larsen M, Hagen KB, Krogstad A-L, Aas E, Klopstad Wahl A. Limited evidence of the effects of patient education and self-management interventions in psoriasis patients: a systematic review. Patient Educ Couns. 2014;94:158-69.

73. Smith F, Carlsson E, Kokkinakis D, Forsberg M, Kodeda K, Sawatzky R, Friberg F, Öhlén J. Readability, suitability and comprehensibility in patient education materials for Swedish patients with colorectal cancer undergoing elective surgery: a mixed method design. Patient Educ Couns. 2014;94:202-9.

74. Antonovsky A. The sense of coherence as a determinant of health. In: Matarazzo JD, Weiss SM, Herd JA, et al., editors. Behavioral health. New York: Wiley; 1984. p. 114-29.

75. Mittelmark MB, Sagy S, Eriksson M, Bauer GF, Pelikan JM, Lindström B, Espnes GA, editors. The handbook of Salutogenesis. Berlin: Springer; 2017. https://doi.org/10.1007/978-3-319-04600-6.

Open Access This chapter is licensed under the terms of the Creative Commons Attribution 4.0 International License (http://creativecommons.org/licenses/by/4.0/), which permits use, sharing, adaptation, distribution and reproduction in any medium or format, as long as you give appropriate credit to the original author(s) and the source, provide a link to the Creative Commons license and indicate if changes were made.

The images or other third party material in this chapter are included in the chapter's Creative Commons license, unless indicated otherwise in a credit line to the material. If material is not included in the chapter's Creative Commons license and your intended use is not permitted by statutory regulation or exceeds the permitted use, you will need to obtain permission directly from the copyright holder. 